\title{
PENGARUH TINGKAT PENDIDIKAN, PENGETAHUAN AKUNTANSI DAN PELATIHAN AKUNTANSI TERHADAP PENGGUNAAN INFORMASI AKUNTANSI DIMODERASI KETIDAKPASTIAN LINGKUNGAN USAHA KECIL MENENGAH
}

\author{
Choirul Hudha, Pascasarjana Universitas Negeri Surabaya \\ hudha88.unesa@gmail.com
}

\begin{abstract}
ABSTRAK
Penelitian ini bertujuan untuk menguji dan menganalisis pengaruh tingkat pendidikan, pengetahuan akuntansi dan pelatihan akuntansi terhadap penggunaan informasi akuntansi, serta menguji dan menganalisis ketidakpastian lingkungan dalam memoderasi pengaruh tingkat pendidikan, pengetahuan akuntansi dan pelatihan akuntansi terhadap penggunaan informasi akuntansi. Populasi dalam penelitian ini adalah pemilik Usaha Kecil Menengah (UKM) Kota Surabaya sebanyak 514 pemilik UKM. Sampel dipilih berdasarkan proportional random sampling dan terpilih sebanyak 225 pemilik UKM. Teknik pengumpulan data menggunakan kuesioner, wawancara, dan dokumentasi. Metode analisis data menggunakan Structural Equation Modelling (SEM). Hasil penelitian menunjukkan bahwa variabel tingkat pendidikan tidak berpengaruh terhadap penggunaan informasi akuntansi pada UKM. Pengetahuan akuntansi dan pelatihan akuntansi berpengaruh signifikan terhadap penggunaan informasi akuntansi pada UKM. Ketidakpastian lingkungan sebagai variabel moderasi memoderasi pengaruh tingkat pendidikan, pengetahuan akuntansi dan pelatihan akuntansi terhadap penggunaan informasi akuntansi.
\end{abstract}

Kata Kunci: Tingkat Pendidikan, Pengetahuan Akuntansi, Pelatihan Akuntansi, Informasi Akuntansi dan Ketidakpastian Lingkungan.

\begin{abstract}
The purpose of the study were to examine and analyze the influence of education level, accounting knowledge, accounting training on the use of accounting information, and to examine and analyze the environmental uncertainty as a moderating variable that influence the education level, accounting knowledge and accounting training on the use of accounting information. The number of population in this research were 514 owners of Small and Medium Enterprises (SMEs) in Surabaya. The sample selection in this research based on proportional random sampling and choosen 225 owners of the SMEs. The data collection techniques used questionnaires, interviews, and documentation. The analyze method used Structural Equation Modelling (SEM). The results showed that the education level did not significantly influence the use of accounting information. The accounting knowledge and accounting training significantly influence the use of accounting information on SMEs. The
\end{abstract}


environmental uncertainty as a moderating variable moderated the influence of education level, accounting knowledge, and accounting training on the use of accounting information.

Keywords: Education level, accounting knowledge, accounting training, accounting information, and environmental uncertainty.

\section{PENDAHULUAN}

Usaha Kecil Menegah (UKM) merupakan salah satu kegiatan ekonomi strategis yang memiliki peran penting bagi pertumbuhan ekonomi negara maju maupun negara berkembang. Peranan penting yang dimaksud adalah selain mampu melakukan perluasan pada kesempatan usaha, UKM juga memberikan manfaat seperti perluasan kesempatan kerja yang selama ini dibutuhkan masyarakat dalam menunjang kebutuhan ekonomi sehari-hari. Selain itu UKM juga dapat memberikan kontribusi positif baik secara makro maupun mikro yaitu dengan terserapnya angkatan kerja, meningkatnya permintaan, meningkatnya daya beli masyarakat serta pertumbuhan investasi. Oleh karena itu Usaha Kecil Menengah (UKM) menjadi salah satu pilar penting bagi pertumbuhan ekonomi di Indonesia.

Perkembangan Usaha Kecil dan Menengah (UKM) tercatat pada tahun 2011 mampu meningkatkan PDB Indonesia sebesar Rp. 4.000 triliun atau hampir $60 \%$ dari seluruh total PDB Indonesia yang telah dihasilkan. Selain itu, sektor UKM baik industri maupun perdagangan mampu memberikan kontribusi lainnya seperti penyerapan tenaga kerja yang terjadi pada tahun 2011 yaitu sebanyak 97,24\% atau 101,7 juta tenaga kerja dari seluruh tenaga kerja yang terdapat di Indonesia. (Departemen Koperasi dan Usaha Mikro, Kecil Menengah, 2012).

Usaha Kecil Menegah (UKM) selain mempunyai peran yang strategis, proses dalam pengelolaan dan pengembangannya tidaklah mudah, karena banyak ditemukan kendala yang cukup komplek baik berasal dari internal maupun eksternal. Penelitian Barbara, et al (2000) mengungkapkan bahwa permasalahan yang harus dihadapi oleh perusahaan kecil antara lain bidang pemasaran, keuangan, dan manajemen sangat berpengaruh terhadap pengembangan perusahaan kecil dan menengah. Sedangkan penelitian yang dilakukan oleh Sih Darmi Astuti dan J.Widiatmo (2003) menjelaskan bahwa masalah umum yang dihadapi oleh pengusaha kecil dan menengah adalah keterbatasan terhadap modal kerja, kesulitan bahan baku, keterbatasan teknologi, sumber daya manusia dengan kualitas yang baik, serta informasi dan pemasaran.

Penggunaan informasi akuntansi pada Usaha Kecil Menengah (UKM) merupakan salah satu upaya dalam mengantisipasi kegagalan usaha yang dijalankan. Selain itu, informasi akuntansi dapat memberikan dan menyajikan informasi penting yang relevan untuk mengetahui apakah kinerja usaha yang dijalankan sesuai dengan harapan atau tidak, lebih spesifik dijelaskan bahwa penggunaan informasi akuntansi pada perusahaan kecil akan membantu pihak manajemen dalam melakukan perencanaan, kontrol, pengambilan kebijakan dan evaluasi kinerja terhadap perusahaan. Penelitian oleh Mitchell, et al (2000) menjelaskan bahwa dalam konteks perusahaan kecil, informasi akuntansi 
merupakan faktor penting dalam pengelolaan usaha yang dijalankan serta diperlukan dalam merumuskan berbagai keputusan untuk memecahkan permasalahan antara lain seperti biaya, pengeluaran dan arus kas tentunya dengan informasi yang relevan untuk mendukung kontrol dan monitoring yang dilakukan.

Ismail dan King (2005) juga menjelaskan bahwa informasi akuntansi yang digunakan oleh perusahaan kecil dalam kondisi lingkungan yang dinamis dan kompetitif dapat membantu perusahaan kecil untuk mengambil inisiatif keputusan dalam menyelesaikan permasalahan yang menyangkut kegiatan operasional perusahaan tanpa melakukan strategi perencanaan jangka panjang. Penelitian Son, et al (2006) juga menyebutkan bahwa informasi akuntansi yang dihasilkan adalah relevan, maka pihak manajemen akan mengetahui bagaimana solusi yang akan dilakukan terhadap masalah yang timbul menyangkut hal operasional perusahaan kecil.

Penelitian yang dilakukan Gudono (2007) yang merangkum pendapat Gordon dan Miller bahwa informasi akuntansi merupakan salah satu alat yang dapat digunakan manajemen untuk membantu menghadapi persaingan bisnis, juga dapat memberikan informasi relevan dan tepat waktu dalam melakukan perencanaan, pengendalian, pembuatan keputusan dan evaluasi kinerja, selain itu informasi akuntansi juga digunakan untuk mengimplementasikan strategi dan melakukan aktivitas operasional yang diperlukan untuk mencapai tujuan organisasi secara keseluruhan. Grande, et al (2011) juga mengungkapkan bahwa penggunaan informasi akuntansi pada perusahaan kecil di Spanyol memiliki hubungan positif dalam mengukur dan menentukan produktivitas serta kinerja keuangan perusahaan kecil dengan akurat.

Penelitian yang dilakukan oleh Holmes dan Nicholls (1988) meneliti tentang faktor-faktor yang mempengaruhi penggunaan informasi akuntansi pada 928 perusahaan kecil di Australia, mengungkapkan bahwa tingkat pendidikan, pengetahuan akuntansi, skala usaha, masa memimpin usaha dan pelatihan akuntansi memiliki pengaruh positif terhadap penggunaan informasi akuntansi. Penelitian yang sama dilakukan oleh Fitriyah (2006) menyatakan bahwa variabel pengetahuan akuntansi, skala usaha, pengalaman usaha dan jenis usaha berpengaruh positif terhadap penggunaan informasi akuntansi, dan ketidakpastian lingkungan sebagai variabel moderasi memperkuat adanya hubungan tersebut.

Penelitian Astuti (2007) juga mengungkapkan bahwa skala usaha, masa memimpin dan pelatihan akuntansi berpengaruh positif terhadap penggunaan informasi akuntansi, sedangkan variabel tingkat pendidikan dan umur perusahaan tidak memiliki hubungan positif. Sedangkan hasil penelitian yang dilakukan oleh Wahyudi (2009) menjelaskan bahwa variabel tingkat pendidikan pemilik atau manajer, skala usaha mempunyai hubungan positif terhadap penggunaan informasi akuntansi sedangkan masa memimpin usaha, umur perusahaan dan pelatihan akuntansi tidak memiliki hubungan positif. Hasil penelitian yang dilakukan oleh Shields dan Shelleman (2011) juga mengungkapkan bahwa pelatihan akuntansi yang berupa penggunaan program software akuntansi yang dilakukan pada 128 perusahaan kecil meningkatkan intensitas penggunaan informasi akuntansi manajemen pada bisnis yang telah dilakukan. 
Penelitian yang dilakukan oleh Nalukenge, et al (2012) juga menjelaskan bahwa tingkat pendidikan, tekanan lingkungan eksternal, pengetahuan akuntansi, dan umur usaha memiliki hubungan positif terhadap kualitas informasi akuntansi yang dihasilkan. Sebaliknya ukuran usaha tidak memiliki hubungan positif terhadap kualitas informasi akuntansi yang dihasilkan. Sedangkan penelitian Chiliya dan Lombart (2012) mengungkapkan bahwa tingkat pendidikan dan tingkat pengalaman antara lain umur perusahaan dan umur para pemilik usaha kecil di Afrika Selatan berpengaruh positif terhadap penggunaan informasi akuntansi dalam meningkatkan kinerja keuangan.

Penelitian Lasdi dan Mulia (2014) juga menjelaskan pengetahuan akuntansi, skala usaha dan pengalaman usaha berpengaruh positif terhadap penggunaan informasi akuntansi, tetapi jenis usaha tidak memiliki pengaruh positif terhadap penggunaan informasi akuntansi, sedangkan ketidakpastian lingkungan memoderasi atau memperkuat hubungan pengaruh variabel pengetahuan akuntansi, pengalaman usaha dan jenis usaha terhadap penggunaan informasi akuntansi tetapi tidak pada variabel skala usaha.

Surabaya merupakan salah satu kota yang dianggap berhasil dalam pengembangan ekonomi masyarakat melalui pemberdayaan Usaha Kecil Menengah (UKM). Perkembangan UKM di kota Surabaya setiap tahunnya mengalami kenaikan yang positif baik dilihat dari sisi kuantitas maupun produktivitasnya, sehingga efek perkembangan UKM di kota Surabaya memberikan dampak positif bagi perkembangan UKM di daerah-daerah lainnya seperti kabupaten Sidoarjo dan Gresik (Dinas Koperasi dan UMKM Kota Surabaya, 2014).

Produk Domestik Regional Bruto (PDRB) kota Surabaya dalam tiga tahun terakhir mengalami trend yang cukup positif, peningkatan tersebut bukan hanya semata-mata di peroleh dari industri-industri besar yang ada di kota Surabaya, melainkan peranan yang cukup positif oleh UKM. Pada tahun 2011, PDRB kota Surabaya mencapai 235.034.299,43. Selanjutnya pada tahun 2012 sebesar 264.335.620,09. Sedangkan di tahun 2013 mencapai 305.689.586,81. Peningkatan lainnya adalah secara kuantitatif jumlah UKM di kota Surabaya juga mengalami kenaikan, pada tahun 2011 jumlah UKM mencapai 4.673 unit, kemudian pada tahun 2012 mencapai 4.835 unit dengan total produksi tahun 2012 mencapai 27.116.451 yang sebelumnya hanya mencapai sebesar 9.937.993. Berdasarkan data diatas, peranan UKM bagi kota Surabaya cukup positif dalam menggerakkan roda perekonomian di kota Surabaya (BPS Kota Surabaya, 2014).

Strategi pengembangan UKM di kota Surabaya dilakukan dengan pengembangan sentra usaha yang membentuk cluster-cluster yang dinamakan dengan kampung UKM unggulan. Jenis usaha yang dilakukan juga beragam, secara kuantitas dan kualitas UKM Unggulan kota Surabaya sangat terjaga dibuktikan dengan perkembangan yang cukup pesat terhadap produk-produk yang dihasilkan mempunyai standar kualitas yang terstandar dan dapat menembus pasar ekspor. Upaya tersebut dilakukan adalah untuk persiapan dan persaingan dalam menghadapi Masyarakat Ekonomi ASEAN (Disperdagin Kota Surabaya, 2014).

Dinas Koperasi dan UMKM Jawa Timur mengungkapkan bahwa para pelaku usaha kecil baru yang terus tumbuh membutuhkan binaan, baik dari segi 
permodalan maupun pendampingan. Selain itu, dengan adanya perhatian yang serius diharapkan UKM akan terus berkembang sehingga penyokong terbesar perekonomian Jawa Timur tersebut tidak mati. Hal itu juga diperkuat kembali oleh pendapat dari ketua Forum Daerah Usaha Kecil Menengah Jawa Timur yang mengungkapkan bahwa selain inovasi yang kurang dilakukan oleh UKM serta tingginya upah minimum pegawai yang bekerja di sektor UKM, sektor lain seperti infrastruktur dan permodalan yang sangat minim harus segera diperbaiki karena permodalan yang dilakukan pemerintah saat ini adalah dengan memberikan dana pinjaman dengan nilai nominal yang sama padahal sektor usaha yang dijalankan beragam (Jawa Pos, 2014).

Permasalahan lainnya adalah banyaknya produk-produk impor dari luar negeri yang membanjiri pasar lokal Surabaya. Produk yang di impor tersebut selain memiliki harga yang lebih murah, kualitas produk yang dihasilkan juga sama dengan produk lokal sehingga membuat usaha kecil menengah semakin sulit untuk bersaing dan mengembangkan usaha apalagi dengan tanpa bantuan modal. Selain faktor internal yang harus diperbaiki oleh para pemilik UKM dalam mengelola usahanya. Oleh karena itu penggunaan informasi akuntansi yang baik sangat diperlukan untuk memperoleh tambahan modal usaha atau kredit dengan cepat sehingga dapat digunakan dalam menunjang usaha yang dijalankan agar lebih berkembang dan bersaing secara kompetitif dengan usaha lainnya.

Tingkat pendidikan pemilik Usaha Kecil Menengah (UKM) menjadi salah satu faktor penyebab lemahnya pengelolaan serta pengembangan usaha kecil menengah yang dilakukan dalam menggunakan informasi akuntansi. Pelaku kampung UKM Unggulan Kota Surabaya masih beranggapan bahwa akuntansi adalah hal yang menyulitkan untuk dilakukan dan justru akan menjadi beban tersendiri, sehingga dalam benak mereka saat ini adalah bagaimana usaha yang dilakukan berjalan lancar dan bagaimana untuk mendapatkan keuntungan yang sebesar-besarnya dari usaha yang dijalankan tanpa memperhatikan betapa besar manfaat yang diperoleh dari penggunaan informasi akuntansi yang baik dalam pengelolaannya.

Pelaku UKM pada kampung unggulan kota Surabaya mempunyai keterbatasan dalam menggunakan informasi akuntansi pada pengelolaan usaha yang dijalankan, sehingga hal tersebut berakibat pada pengajuan kredit yang telah diajukan kepada pihak perbankan menjadi terhambat karena tambahan modal yang sangat dibutuhkan UKM tidak diberikan. Informasi akuntansi yang tidak relevan diperoleh pihak perbankan menjadi acuan sebagai pertimbangan untuk tidak memberikan kredit, karena pihak perbankan tidak mau mengambil resiko yang berakibat akan menimbulkan masalah seperti kredit macet dan lain sebagainya.

Ihsan (2011) juga menjelaskan bahwa jenjang pendidikan adalah tahap pendidikan yang berkelanjutan yang ditetapkan berdasarkan tingkat perkembangan peserta didik, tingkat kerumitan bahan pengajaran dan cara menyajikan bahan pengajaran dan jenjang pendidikan sekolah terdiri dari pendidikan dasar, pendidikan menengah dan pendidikan tinggi.

Menurut Pasal 14 Undang-Undang Republik Indonesia Nomor 20 Tahun 2003 tentang Sistem Pendidikan Nasional menyatakan bahwa jenjang pendidikan formal terdiri atas pendidikan dasar, pendidikan menengah dan 
pendidikan tinggi. (a) Pendidikan Dasar, Menurut Undang-Undang Republik Indonesia No.20 Tahun 2003 Pasal 17 tentang sistem pendidikan nasional: pendidikan dasar merupakan jenjang pendidikan yang melandasi jenjang pendidikan menengah. Pendidikan dasar berbentuk Sekolah Dasar (SD) dan Madrasah Ibtidaiyah (MI) atau bentuk lain yang sederajat serta Sekolah Menengah Pertama (SMP) dan Madrasah Tsanawiyah (MTs), atau bentuk lain yang sederajat. Hal ini karena adanya pendidikan wajib belajar (wajar) Sembilan tahun. Menurut Ihsan (2011) pengertian pendidikan dasar adalah pendidikan yang memberikan pengetahuan dan keterampilan, menumbuhkan sikap dasar yang diperlukan dalam masyarakat, serta mempersiapkan peserta didik untuk mengikuti pendidikan menengah. Sedangkan pendidikan menengah adalah merupakan lanjutan pendidikan dasar. (b) Pendidikan Menengah, Undang-Undang Republik Indonesia Nomor 20 Tahun 2003 Pasal 17 tentang sistem pendidikan nasional: pendidikan menengah terdiri atas pendidikan menengah umum dan pendidikan menengah kejuruan. Pendidikan menengah berbentuk sekolah menengah atas (SMA), madrasah aliyah (MA), sekolah menengah kejuruan (SMK), dan madrasah aliyah kejuruan (MAK), atau bentuk lain yang sederajat. Ihsan (2011) juga menyatakan bahwa pendidikan menengah adalah pendidikan yang mempersiapkan peserta didik menjadi anggota masyarakat yang memiliki kemampuan mengadakan hubungan timbal balik dengan lingkungan sosial budaya, dan alam sekitar, serta diharapkan mampu mengelola mengembangkan kemampuan lebih lanjut dalam dunia kerja atau pendidikan. (c) Pendidikan Tinggi, Menurut Undang Undang Republik Indonesia No. 20 Tahun 2003 Pasal 17 tentang sistem pendidikan nasional: pendidikan tinggi merupakan jenjang pendidikan setelah pendidikan menengah yang mencakup program pendidikan diploma, sarjana, magister, spesialis, dan doktor yang diselenggarakan oleh perguruan tinggi. Perguruan tinggi dapat berbentuk akademi, politeknik, sekolah tinggi, institute dan universitas.

Pengetahuan akuntansi juga memiliki andil besar dalam kemajuan usaha yang dikelola. Pengetahuan akuntansi yang dimiliki oleh pemilik usaha kecil menengah akan banyak memberikan banyak manfaat dalam penggunaan informasi akuntansi. Pengetahuan akuntansi yang rendah akan menyebabkan usaha yang dijalankan mengalami kegagalan manajemen sehingga sangat sulit bagi para pelaku usaha dalam menentukan kebijakan apa yang akan diambil. Pengetahuan akuntansi yang dimiliki oleh pemilik usaha kecil menengah kampung UKM unggulan Kota Surabaya saat ini masih hanya sebatas pengetahuan tentang bagaimana pemasukan dan pengeluaran kas. Kemudian pada laporan keuangan usahanya pemilik usaha juga hanya sebatas mengetahui apakah usaha yang dijalankan mengalami keuntungan atau kerugian semata. Informasi akuntansi tidak hanya sebatas itu, melainkan dengan penggunaan informasi akuntansi akan dapat menggambarkan kondisi usaha yang lebih lengkap dan komprehensif sehingga informasi yang dihasilkan akan lebih akurat. Penggunaan informasi akuntansi dalam praktiknya akan memberikan data-data terkait bagaimana usaha yang dijalankan secara keseluruhan misalnya dengan menggunakan informasi akuntansi akan terlihat jelas bagaimana informasi statutori, informasi anggaran, dan informasi tambahan. Salah satu manfaat yang bisa di dapat antara lain bagaimana mengetahui rasio keuangan 
usaha bisa dilihat dari laporan sehingga pemilik akan mengetahui bagaimana kondisi kesehatan keuangan pada usaha yang dijalankan.

Penelitian Bonner dan Walker (1994); dan Spilker (1995) menjelaskan bahwa indikator yang diambil pada variabel pengetahuan akuntansi dalam penelitiannya adalah pengetahuan deklaratif dan prosedural. Pengetahuan deklaratif merupakan pengetahuan tentang fakta-fakta serta berdasarkan konsep. Sebagai contoh: kas adalah bagian dari harta lancar, pengetahuan ini memudahkan bagaimana cara dalam menganalisis rasio keuangan, sedangkan pengetahuan prosedural merupakan pengetahuan yang konsisten dengan aturan-aturan yang telah ditetapkan.

Pelatihan akuntansi yang diikuti pemilik usaha pada kampung UKM unggulan kota Surabaya juga akan dapat meningkatkan pengetahuan tentang bagaimana penggunaan informasi akuntansi yang baik dalam mengelola usaha yang dijalankan. Saat ini sebagian besar pemilik Usaha Kecil Menengah (UKM) unggulan kota Surabaya masih apatis dan mengabaikan pelatihanpelatihan yang diadakan karena mereka menganggap pelatihan tersebut hanya membuang-buang waktu, terkadang setelah pelatihan sudah dilakukan para pemilik UKM juga tidak bisa menerapkan secara utuh apa yang sudah diajarkan karena menganggap hal yang diperoleh masih terlalu rumit untuk dilakukan oleh pemilik UKM kampung unggulan kota Surabaya.

Holmes dan Nicholls (1988 \& 1989) mengungkapkan bahwa pelatihan akuntansi juga menjadi salah satu faktor penting dalam penggunaan informasi akuntansi untuk membuat keputusan. Manajemen yang digunakan dalam pelaksanaan kursus atau pelatihan cenderung menghasilkan lebih banyak informasi akuntansi statutory, anggaran dan tambahan dibandingkan dengan mereka yang kurang dalam mengikuti pelatihan. Penelitian Grace (2003) juga menjelaskan bahwa pelatihan akuntansi merupakan salah satu faktor penting dalam penggunaan informasi akuntansi yang dilakukan oleh UKM di Jawa Tengah.

Hasil penelitian juga dilakukan Astuti (2007) yang menjelaskan bahwa pelatihan akuntansi yang diikuti akan menambah skill pemilik UKM sehingga akan memiliki hubungan positif dalam penggunaan informasi akuntansi usaha kecil menengah di kabupaten Kudus. Indikator yang digunakan dalam penelitian tersebut antara lain yaitu (a) keikutsertaan pemilik usaha dalam kegiatan pelatihan akuntansi, (b) perlunya pelatihan sesuai dengan bidang usaha untuk meningkatkan kinerja, (c) kesediaan mengikuti pelatihan akuntansi dan (d) pelatihan penting untuk memperbaiki kinerja.

Keterbatasan penggunaan informasi akuntansi yang dibiarkan begitu saja akan menjadi kelemahan serta akan menjadi kegagalan manajemen dalam melakukan pengelolaan dan pengembangan usaha yang dijalankan. Penggunaan informasi akuntansi penting untuk dilakukan karena akan memberikan dampak serta manfaat terhadap usaha yang dilakukan sehingga menjadi terarah dan terencana. Selain itu, dengan kondisi ketidakpastian lingkungan yang tidak bisa diprediksi akan membuat para pelaku usaha kecil menengah semakin sulit dalam menentukan keputusan yang tepat bagi usahanya, karena pelaku UKM masih belum bisa mengetahui apa yang akan terjadi dimasa mendatang seperti halnya: harga bahan baku, kemajuan 
teknologi, peraturan pemerintah, peluang pasar, kondisi ekonomi politik yang tidak menentu serta persaingan usaha yang semakin kompetitif.

Belkaoui (2000) juga mendefinisikan informasi akuntansi sebagai informasi kuantitatif tentang entitas ekonomi yang bermanfaat untuk pengambilan keputusan ekonomi dalam menentukan pilihan-pilihan diantara alternatif-alternatif tindakan. Sedangkan menurut Haswell dan Holmes (1989) menjelaskan bahwa keterbatasan penggunaan informasi akuntansi dalam manajemen perusahaan dapat membahayakan perusahaan kecil. Selanjutnya mereka juga menyatakan bahwa kondisi keuangan yang memburuk dan kekurangan catatan akuntansi akan membatasi akses untuk memperoleh informasi yang diperlukan, sehingga akan menyebabkan kegagalan perusahaan.

Mc Mahon (2001) juga menjelaskan bahwa informasi akuntansi seperti neraca, laporan laba rugi, laporan arus kas dan rasio keuangan akan dapat meningkatkan prestasi/kinerja perusahaan kecil dalam menjalankan aktivitas operasionalnya. Sedangkan Holmes dan Nicholls (1988 \& 1989) menjelaskan dan mengklasifikasikan informasi akuntansi dalam tiga jenis yang berbeda menurut manfaatnya bagi para pemakai yaitu:

1. Statutory accounting information, merupakan informasi yang harus disiapkan sesuai dengan peraturan yang ada.

2. Budgetary information, yaitu informasi akuntansi yang disajikan dalam bentuk anggaran yang berguna bagi pihak internal dalam perencanaan, penilaian dan pengambilan keputusan.

3. Additional accounting information, yaitu informasi akuntansi lain yang disiapkan perusahaan guna meningkatkan efektivitas pengambilan keputusan.

Penelitian ini dilakukan adalah untuk menguji dan menganalisis pengaruh variabel tingkat pendidikan, pengetahuan akuntansi dan pelatihan akuntansi terhadap penggunaan informasi akuntansi serta menguji dan menganalisis variabel ketidakpastian lingkungan sebagai variabel moderasi pada pengaruh hubungan tersebut. Sehingga berdasarkan latar belakang penelitian ini penulis akan mengangkat sebuah penelitian dengan judul pengaruh tingkat pendidikan, pengetahuan akuntansi dan pelatihan akuntansi terhadap penggunaan informasi akuntansi dengan ketidakpastian lingkungan sebagai variabel moderasi Usaha Kecil Menengah (UKM) Kota Surabaya.

\section{METODE PENELITIAN}

Pendekatan yang digunakan dalam penelitian ini adalah menggunakan pendekatan kuantitatif. Sedangkan untuk jenis penelitian ini adalah penelitian survey eksplanatori (Survey Explanatory Research). Variabel yang digunakan dalam penelitian ini adalah sebagai berikut untuk variabel bebas antara lain: Tingkat pendidikan $\left(\mathrm{X}_{1}\right)$, Pengetahuan akuntansi $\left(\mathrm{X}_{2}\right)$, dan Pelatihan akuntansi $\left(\mathrm{X}_{3}\right)$, sedangkan untuk variabel terikat adalah: Penggunaan informasi akuntansi (Y). sedangkan untuk variabel moderasi dalam penelitian ini adalah Ketidakpastian lingkungan $(Z)$.

Indikator yang digunakan dalam penelitian ini untuk variabel tingkat pendidikan adalah menurut Holmes \& Nicholls (1988), Grace (2003), Astuti (2007) menggunakan pendidikan dasar (SD Sederajat), pendidikan menengah 
(SMP, SMA sederajat) dan pendidikan tinggi (Diploma dan Sarjana), kemudian indikator yang digunakan untuk variabel pengetahuan akuntansi adalah menurut Holmes \& Nicholls (1988), Fitriyah (2006) dan Lasdi \& Mulia (2014) yaitu pengetahuan deklaratif dan pengetahuan prosedural, sedangkan pada variabel pelatihan akuntansi menggunakan indikator menurut Holmes \& Nicholls (1988), Grace 2003 dan Astuti (2007) antara lain: keikutsertaan responden dalam pelatihan, perlunya pelatihan sesuai bidang usaha untuk meningkatkan kinerja, kesediaan mengikuti pelatihan dan pelatihan penting untuk memperbaiki kinerja. Sedangkan untuk variabel penggunaan informasi akuntansi dalam penelitian ini menggunakan indikator menurut Holmes \& Nicholls (1988) yaitu informasi statutory, informasi anggaran dan informasi tambahan. Untuk variabel moderasi ketidakpastian lingkungan menggunakan menurut pendapat antara lain: Duncan (1972), Miliken (1987), Fisher (1996) dan Darlis (2002) yaitu informasi yang berkaitan dengan kondisi usaha dimasa yang akan datang, informasi tentang pengaruh faktor-faktor eksternal seperti kondisi ekonomi, teknologi dan lain-lain dan informasi yang berkaitan dengan non ekonomi seperti peraturan pemerintah, persaingan usaha, peluang pasar, prediksi harga dan lain-lain.

Populasi yang digunakan dalam penelitian ini adalah pemilik Usaha Kecil Menengah (UKM) Kota Surabaya sebanyak 514 pemilik UKM dengan jumlah sampel yang digunakan sebanyak 225 pemilik UKM. Teknik pengumpulan data yang digunakan dalam penelitian ini adalah dengan menggunakan kuesioner, wawancara dan dokumentasi. Sedangkan metode analisis data yang digunakan pada penelitian adalah menggunakan Structural Equation Modelling (SEM).

\section{HASIL PENELITIAN DAN PEMBAHASAN}

Tahapan awal yang dilakukan sebelum menganalisis data penelitian adalah menyusun atau merancang model struktural (inner model) dan model pengukuran (outer model). Hal tersebut dilakukan untuk melakukan design model yang diinginkan peneliti sesuai konsep yang direncanakan selain itu perancangan model struktural dilakukan adalah bagaimana path diagram yang akan dibentuk sesuai dengan teori dan hipotesis yang telah dibentuk dalam penelitian. Tahap ini juga digunakan model pengukuran (outer model) yaitu pengukuran masing-masing indikator terhadap konstruk variabel laten. Dalam penelitian ini menggunakan indikator reflektif dalam mengukur konstruk variabelnya yaitu variabel konstruk yang membentuk indikator bukan sebaliknya indikator yang akan membentuk konstruk (indikator formatif). Perancangan model struktural (inner model) dan pengukuran model (outer model).

Berdasarkan gambar diatas dapat dijelaskan bahwa indikator pada model tahap kedua secara keseluruhan mengkonstruk variabel sesuai dengan convergent validity. Hal tersebut dijelaskan dari variabel eksogen tingkat pendidikan memiliki nilai loading factor lebih besar dari 0,5 yaitu sebesar 1,000. Sedangkan untuk variabel eksogen pengetahuan akuntansi (PAK) memiliki loading factor antara lain untuk PAK1 sebesar 0,826 serta untuk PAK2 0,825 Selanjutnya untuk variabel eksogen pelatihan akuntansi (PELAK) 
pada model gambar diatas dapat dijelaskan juga antara lain untuk indikator PELAK1 memiliki nilai loading factor sebesar 0,616 sedangkan pada indikator PELAK2 memiliki nilai loading factor sebesar 0,780 dan selanjutnya untuk indikator PELAK4 sebesar 0,681. Variabel moderasi untuk Ketidakpastian Lingkungan (KL) memiliki indikator yang juga memenuhi syarat convergent validity artinya dapat dilihat dari nilai KL1 memiliki nilai loading factor sebesar 0,721, kemudian untuk KL2 sebesar 0,836 dan KL3 sebesar 0,713. Sedangkan untuk variabel endogen penggunaan informasi akuntansi (PIA) semua juga memenuhi syarat dalam kriteria convergent validity hal tersebut dapat dilihat pada indikator PIA1 memiliki nilai loading factor sebesar 0,782 kemudian PIA2 sebesar 0,778 dan indikator ketiga yaitu PIA3 memiliki nilai loading factor sebesar 0,774 774 selain itu dari beberapa penjelasan diatas dapat dijelaskan pada tabel 1 berikut:

Tabel 1. Convergent Validity

\begin{tabular}{|l|c|c|}
\hline \multicolumn{1}{|c|}{ Indikator } & Nilai Outer Loading & Kriteria \\
\hline TP & 1,000 & Valid \\
\hline PAK1 & 0,826 & Valid \\
\hline PAK2 & 0,825 & Valid \\
\hline PELAK1 & 0,616 & Valid \\
\hline PELAK3 & 0,780 & Valid \\
\hline PELAK4 & 0,681 & Valid \\
\hline KL1 & 0,721 & Valid \\
\hline KL2 & 0,836 & Valid \\
\hline KL3 & 0,713 & Valid \\
\hline PIA1 & 0,782 & Valid \\
\hline PIA2 & 0,778 & Valid \\
\hline PIA3 & 0,774 & Valid \\
\hline
\end{tabular}

Hasil outer model dan inner model juga menjelaskan tentang uji realibilitas variabel tingkat pendidikan (TP), Pengetahuan Akuntansi (PAK), Pelatihan Akuntansi (PELAK), Ketidakpastian Lingkungan (KL) dan Penggunaan Informasi Akuntansi (PIA) dengan melihat nilai composite reliability yang dihasilkan dari perhitungan oleh PLS. Nilai suatu variabel dikatakan reliabel jika memberikan nilai composite variabel $>0,70$ dan variance extracted > 0,05 (Werts et. al 1974 dalam Ghozali, 2006) dibawah ini akan menjelaskan nilai composite variabel dan variance extracted masingmasing variabel tingkat pendidikan, pengetahuan akuntansi, pelatihan akuntansi, penggunaan informasi akuntansi dan ketidakpastian lingkungan yang disajikan pada tabel 2 berikut:

Tabel 2. Composite Variabel dan Variance Extracted

\begin{tabular}{|c|l|c|c|c|}
\hline No & Variabel & AVE & Composite Reliability & Keterangan \\
\hline 1 & TP & 0.571 & 1.000 & Reliabel \\
\hline 2 & PAK & 0.662 & 0.811 & Reliabel \\
\hline 3 & PELAK & 0.734 & 0.736 & Reliabel \\
\hline 4 & PIA & 0.776 & 0.822 & Reliabel \\
\hline 5 & KL & 0.576 & 0.802 & Reliabel \\
\hline
\end{tabular}


Data penelitian yang digunakan dalam penelitian ini sebelum tahapan analisis data untuk pengujian hipotesis, tahapan yang dilakukan sebelumnya adalah mencari model yang baik atau fit (Goodness of fit). Dari hasil analisis data diatas menunjukkan bahwa data penelitian telah menunjukkan model yang baik sehingga langkah selanjutnya adalah melakukan pengujian hipotesis (Resampling bootstraping). Hasil yang dilakukan daripada pengujian hipotesis dapat dilihat pada gambar 1 sebagai berikut:

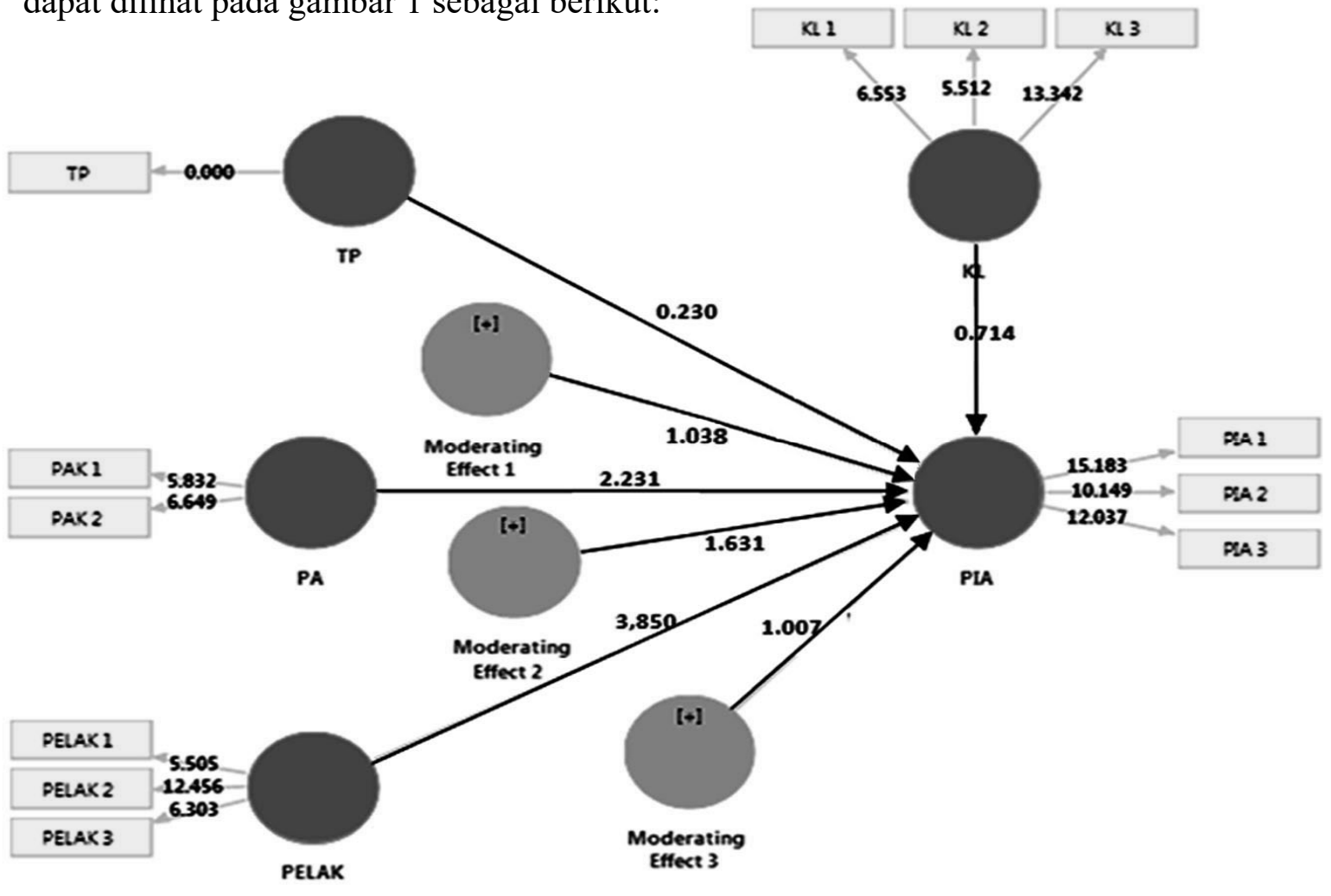

\section{Gambar 1. Output Resampling Bootsraping}

Tabel 3. Hasil Pengujian Hipotesis

\begin{tabular}{|c|c|l|c|c|c|c|}
\hline HIP & \multicolumn{2}{|c|}{ Pengaruh } & Koefisien & $\begin{array}{c}\text { t-statistic } \\
(\text { OSTERR })\end{array}$ & Keterangan \\
\hline H1 & $\begin{array}{c}\text { Tingkat } \\
\text { Pendidikan(X1) }\end{array}$ & $\rightarrow$ & PIA & 0,032 & 0.230 & $\begin{array}{c}\text { Tidak } \\
\text { Signifikan }\end{array}$ \\
\hline H2 & $\begin{array}{c}\text { Pengetahuan } \\
\text { Akuntansi (X2) }\end{array}$ & $\rightarrow$ & PIA & 0.355 & 2,231 & Signifikan \\
\hline H3 & $\begin{array}{c}\text { Pelatihan } \\
\text { Akuntansi (X2) }\end{array}$ & $\rightarrow$ & PIA & 0.414 & 3.850 & Signifikan \\
\hline H4 & $\begin{array}{c}\text { Moderating } \\
\text { Effect1 } \rightarrow \text { KL }\end{array}$ & $\rightarrow$ & PIA & 0.012 & 1.038 & Memoderasi \\
\hline H5 & $\begin{array}{c}\text { Moderating } \\
\text { Effect2 } \rightarrow \text { KL }\end{array}$ & $\rightarrow$ & PIA & 0,052 & 1.361 & Memoderasi \\
\hline H6 & $\begin{array}{c}\text { Moderating } \\
\text { Effect3 } \rightarrow \text { KL }\end{array}$ & $\rightarrow$ & PIA & 0,030 & 1.007 & Memoderasi \\
\hline
\end{tabular}


Hasil pengujian hipotesis dilakukan setelah melalui serangkaian tahapan pengujian hipotesis dengan analisis Structural Equation Modelling (SEM) yaitu apakah model yang digunakan sudah baik (Goodness of fit). Pengujian hipotesis dilakukan untuk mengetahui hubungan antar variabel endogen dan eksogen serta variabel moderating sesuai dengan hipotesis yang telah diajukan. Penelitian ini mengajukan enam hipotesis, adapun hasil pengujian keenam hipotesis tersebut digambarkan pada gambar 1 yang akan secara ringkas disajikan pada tabel 3 .

Berdasarkan tabel 3 diatas maka dapat dibentuk persamaan struktural untuk menguji hipotesis dalam penelitian sebagai berikut:

$$
\begin{aligned}
& \mathrm{M}=0,012 \mathrm{~m}_{1}+\mathbf{0 , 0 5 2} \mathrm{m}_{2}+\mathbf{0 , 0 3 0 \mathrm { m } _ { 3 }} \\
& Y=0,0_{12} X_{1}+0,355 X_{2}+0,414 X_{3}+0,019 K L
\end{aligned}
$$

1. Nilai koefisien jalur tingkat pendidikan (X1) terhadap penggunaan informasi akuntansi (Y) sebesar 0,032. artinya jika tingkat pendidikan naik maka penggunaan informasi akuntansi juga akan naik sebesar 0,032. Sedangkan nilai t statistik sebesar $0,230<1,96$ maka dapat disimpulkan bahwa pengaruh tingkat pendidikan (X1) terhadap penggunaan informasi akuntansi tidak signifikan. Jadi hipotesis pertama (H1) yang menyatakan bahwa tingkat pendidikan berpengaruh positif terhadap penggunaan informasi akuntansi ditolak.

2. Nilai koefisien jalur pengetahuan akuntansi (X2) terhadap penggunaan informasi akuntansi sebesar 0,355. Artinya jika pengetahuan akuntansi naik maka penggunaan informasi akuntansi juga akan naik sebesar 0,032. Sedangkan nilai t statistik sebesar 2,231>1,96 maka dapat disimpulkan bahwa pengaruh pengetahuan akuntansi (X2) terhadap penggunaan informasi akuntansi signifikan. Jadi hipotesis kedua (H2) yang menyatakan bahwa pengetahuan akuntansi berpengaruh positif terhadap penggunaan informasi akuntansi diterima.

3. Nilai koefisien jalur pelatihan akuntansi (X3) terhadap penggunaan informasi akuntansi sebesar 0,414 sedangkan untuk nilai t statistik sebesar 3,850>1,96 maka dapat disimpulkan bahwa pengaruh pelatihan akuntansi (X3) terhadap penggunaan informasi akuntansi signifikan. Jadi hipotesis ketiga (H3) yang menyatakan bahwa pelatihan akuntansi berpengaruh positif terhadap penggunaan informasi akuntansi diterima.

4. Nilai koefisien jalur variabel moderasi ketidakpastian lingkungan sebesar 0,012. Artinya jika ketidakpastian lingkungan memoderasi sebesar 0,012. Sedangkan nilai t statistik sebesar 1,038<1,96 maka dapat disimpulkan bahwa ketidakpastian lingkungan memoderasi tingkat pendidikan (X1) terhadap penggunaan informasi akuntansi (Y) tetapi tidak signifikan. Jadi untuk hipotesis keempat (H4) yang menyatakan bahwa ketidakpastian lingkungan memoderasi tingkat pendidikan terhadap penggunaan informasi akuntansi diterima.

5. Nilai koefisien jalur variabel moderasi ketidakpastian lingkungan sebesar 0,052 artinya ketidakpastian lingkungan memoderasi sebesar 0,052. Sedangkan nilai $\mathrm{t}$ statistik sebesar $1,361<1,96$ maka dapat disimpulkan 
bahwa ketidakpastian lingkungan memoderasi pengetahuan akuntansi (X2) terhadap penggunaan informasi akuntansi (Y) tetapi tidak signifikan. Jadi hipotesis kelima (H5) yang menyatakan bahwa ketidakpastian lingkungan memoderasi tingkat pendidikan terhadap penggunaan informasi akuntansi diterima.

6. Nilai koefisien jalur variabel moderasi ketidakpastian lingkungan sebesar 0,030. Artinya ketidakpastian lingkungan memoderasi sebesar 0,030. Sedangkan nilai $\mathrm{t}$ statistik sebesar $1,007<1,96$ maka dapat disimpulkan bahwa ketidakpastian lingkungan memoderasi pelatihan akuntansi (X3) terhadap penggunaan informasi akuntansi (Y) tetapi tidak signifikan. Jadi hipotesis keenam (H6) yang menyatakan bahwa ketidakpastian lingkungan memoderasi pelatihan akuntansi terhadap penggunaan informasi akuntansi diterima.

\section{Pengaruh tingkat pendidikan terhadap penggunaan informasi akuntansi}

Berdasarkan hasil pengujian hipotesis pertama diperoleh hasil yang menunjukkan bahwa variabel tingkat pendidikan tidak berpengaruh (negatif) terhadap variabel penggunaan informasi akuntansi pada Usaha Kecil Menengah (UKM) Kota Surabaya. Hal ini berarti tingkat pendidikan pemilik UKM yang masih tergolong rendah sangat menentukan dalam penggunaan informasi akuntansi pada usaha yang dijalankan.

Temuan yang dihasilkan oleh penelitian ini adalah bahwa tingkat pendidikan tidak berpengaruh (negatif) terhadap penggunaan informasi akuntansi pada pemilik Usaha Kecil Menengah (UKM) kampung unggulan Kota Surabaya. tingkat pendidikan pemilik UKM di Surabaya kebanyakan masih sampai jenjang sekolah menengah sehingga untuk menerapkan penggunaan informasi akuntansi masih sangat terbatas, hal tersebut dikarenakan masih ada latar pendidikan yang berbeda sehingga informasiinformasi akuntansi sulit untuk diterapkan. Pemilik UKM khususnya di kampung unggulan Kota Surabaya memperoleh pengetahuan mengenai informasi akuntansi (pengelolaan keuangan) melalui penyuluhan-penyuluhan dari dinas terkait yang sifatnya terbatas. Masih minimnya pengetahuan mengenai informasi akuntansi yang mereka (pemilik UKM) dapat dibangku sekolah menyebabkan minimnya juga penggunaan informasi akuntansi dalam mengelola usaha kecil menengah yang mereka jalankan. Apa yang diperoleh dibangku sekolah selama ini berbeda dengan apa yang terjadi di lapangan, karena selama ini di pendidikan formal sekolah menengah sederajat khususnya SMA/MA masih mengajarkan teori-teori semata sehingga ketika kondisi dilapangan yang terjadi sebenarnya (tidak sesuai) akan membuat mereka kembali untuk belajar dari pengalaman-pengalaman tersebut, sehingga solusi yang digunakan untuk menyelesaikan persoalan keuangan juga didapat. Sebaliknya lulusan Sekolah Menengah Kejuruan (SMK) dengan jurusan akuntansi yang sedikit memiliki pengetahuan atau mengerti lebih dalam mengenai penggunaan informasi akuntansi tetapi jumlah lulusan SMK dalam penelitian ini juga sangat terbatas, dikarenakan pada masa pendidikan pemilik UKM, yang dahulu disebut SMEA masih dengan jumlah yang terbatas dan tidak popular. 
Pengaruh negatif (tidak berpengaruh) variabel tingkat pendidikan terhadap penggunaan informasi akuntansi pada Usaha Kecil Menengah (UKM) kampung unggulan Kota Surabaya dapat dikarenakan oleh berbagai sebab antara lain masih rendahnya tingkat pendidikan pemilik UKM yaitu selama ini juga masih berpikir bahwa akuntansi adalah memiliki aturan-aturan yang sangat rumit sehingga para pemilik UKM enggan menggunakan informasi akuntansi pada usaha yang dijalankan. Para pemilik UKM lebih suka melakukan pembukuan keuangan yang sesuai dengan keinginan sendiri oleh karena itu penggunaan informasi akuntansi tidak diterapkan dengan baik oleh pelaku UKM, padahal dalam informasi akuntansi terdapat hal-hal mendasar yang wajib dilakukan guna untuk memperoleh kinerja yang sesuai dengan keinginan pemilik UKM.

Kesimpulan yang diperoleh dari hasil penelitian ini mendukung hasil penelitian yang dilakukan oleh Astuti (2007) dengan menunjukkan bahwa variabel tingkat pendidikan tidak berpengaruh (berpengaruh negatif) terhadap penggunaan informasi akuntansi pada pemilik Usaha Kecil Menengah (UKM) sehingga hipotesis yang diajukan tidak terbukti. Sama halnya dengan hasil penelitian ini yang menjelaskan bahwa tingkat pendidikan tidak berpengaruh (berpengaruh negatif) terhadap penggunaan informasi akuntansi pada Usaha Kecil Menengah (UKM) Kampung Unggulan Kota Surabaya.

\section{Pengaruh pengetahuan akuntansi terhadap penggunaan informasi akuntansi}

Pengujian hipotesis kedua pada penelitian ini menunjukkan hasil bahwa pengetahuan akuntansi memiliki pengaruh positif (berpengaruh) terhadap penggunaan informasi akuntansi pada Usaha Kecil Menengah (UKM) Kota Surabaya. Hal tersebut berarti semakin baik pengetahuan akuntansi yang dimiliki oleh pemilik Usaha Kecil Menengah (UKM) Kota Surabaya maka akan semakin baik pula penggunaan informasi akuntansi yang dilakukan.

Hasil penelitian ini mendukung hasil penelitian lainnya yang dilakukan oleh Suhairi dan Haron (2004) yang menjelaskan bahwa variabel pengetahuan akuntansi berpengaruh terhadap penggunaan informasi akuntansi dalam pengambilan keputusan investasi. Penelitian lainnya yang mendukung Hadiah fitriyah (2006) dan Shonhadji (2009) yang menjelaskan bahwa dalam penelitiannya membuktikan pengetahuan akuntansi berpengaruh terhadap penggunaan informasi akuntansi pada Usaha kecil Menengah (UKM).

Pengetahuan akuntansi berpengaruh signifikan (positif) terhadap penggunaan informasi akuntansi Usaha Kecil Menengah (UKM) Kota Surabaya yang didukung oleh temuan pada variabel pengetahuan akuntansi dalam penelitian ini lebih dominan didukung oleh indikator pengetahuan prosedural. Hal ini dapat ditunjukkan dari temuan dalam penelitian ini bahwa sebagian besar pemilik Usaha Kecil Menengah (UKM) Kota Surabaya mengetahui bahwa laporan keuangan memberikan manfaat terhadap penyimpangan pada usaha yang dikelola, artinya pelaporan keuangan yang dilaporkan harus sesuai dengan kondisi riil operasional usaha karena laporan keuangan dapat memprediksi bagaimana usaha yang dijalankan akan berjalan dengan baik atau tidak, misalnya dalam penjualan produk-produk UKM. Selain itu, pemilik Usaha Kecil Menengah (UKM) juga mengetahui bahwa usaha 
yang dijalankan mendapatkan keuntungan atau kerugian, hal tersebut dapat dilihat pada laporan laba/rugi karena pada laporan tersebut secara jelas tergambar bagaimana pemasukan yang diterima oleh UKM dan pengeluaran yang dikeluarkan dalam proses operasional usahanya.

Pemilik Usaha Kecil Menengah (UKM) juga mengetahui bagaimana laporan keuangan yang baik dan benar dalam pengambilan keputusan usaha artinya laporan keuangan dijadikan dasar sebagai pengambilan keputusan usaha karena faktor keakuratan data yang telah dipaparkan dalam laporan keuangan tersebut sehingga dengan mudah pemilik UKM mampu menjadikan pertimbangan pada setiap pengambilan keputusan. Selain itu, para pemilik Usaha Kecil Menengah (UKM) mengetahui bahwa laporan keuangan dapat menjelaskan apakah usaha yang saya kelola terjadi efisiensi atau terjadi pemborosan, artinya selama operasional usaha yang dilakukan laporan keuangan memberikan gambaran atau informasi yang jelas apakah dalam operasional usaha yang dilakukan lebih banyak biaya yang dikeluarkan atau mengeluarkan biaya yang minimal/efisien.

Temuan lainnya juga didukung oleh variabel penggunaan informasi akuntansi paling dominan didukung oleh indikator pertama yaitu informasi akuntansi statutori. Hal tersebut dapat ditunjukkan dengan hasil temuan bahwa sebagian besar pemilik Usaha Kecil Menengah (UKM) Kota Surabaya menggunakan informasi akuntansi yang telah disesuaikan dengan peraturan yang ada, misalnya dalam menjalankan usahanya laporan keuangan dibuat sesuai dengan aturan-aturan yang berlaku sehingga pemilik mudah dalam memahami dan menginterpretasikan data-data keuangan dengan baik.

Hasil penelitian ini yang menunjukkan bahwa pengetahuan akuntansi berpengaruh positif terhadap penggunaan informasi akuntansi Usaha Kecil Menengah (UKM) mendukung penelitian yang dilakukan oleh Holmes dan Nicholls (1988), Zhou (2010), Lasdi dan Mulia (2014) yang menjelaskan pengetahuan akuntansi berpengaruh positif terhadap penggunaan informasi akuntansi pada usaha kecil menengah (UKM). Penelitian juga mengungkapkan bahwa pengetahuan akuntansi menjadi salah satu prediktor penting yang mempengaruhi penggunaan informasi akuntansi Usaha Kecil Menengah (UKM). Dalam penelitian ini pengetahuan akuntansi juga terbukti menjadi prediktor yang mempengaruhi penggunaan informasi akuntansi Usaha Kecil Menengah (UKM) Kota Surabaya.

\section{Pengaruh pelatihan akuntansi terhadap penggunaan informasi akuntansi}

Berdasarkan hasil pengujian hipotesis tersebut menunjukkan bahwa pelatihan akuntansi mempunyai pengaruh positif (berpengaruh) terhadap penggunaan informasi akuntansi pada Usaha Kecil Menengah (UKM). Hal ini berarti semakin banyak pelatihan akuntansi yang diikuti oleh pemilik UKM maka akan semakin baik penggunaan informasi akuntansi yang dilakukan oleh pemilik Usaha Kecil Menengah (UKM) Kota Surabaya.

Hasil penelitian ini mendukung hasil penelitian sebelumnya antara lain yang dilakukan oleh Holmes dan Nicholls (1988) yang menjelaskan bahwa pelatihan akuntansi berpengaruh terhadap penggunaan informasi akuntansi perusahaan kecil di Australia. penelitian lainnya oleh Shield dan Shelleman (2011) yang juga mengungkapkan bahwa pelatihan akuntansi dengan 
menggunakan aplikasi software accounting berpengaruh positif terhadap penggunaan informasi akuntansi pada UKM Australia bagian barat.

Pelatihan akuntansi berpengaruh signifikan terhadap penggunaan informasi akuntansi Usaha Kecil Menengah (UKM) Kota Surabaya didukung oleh temuan pada variabel pelatihan akuntansi dalam penelitian ini lebih dominan didukung oleh indikator pelatihan akuntansi dapat memperbaiki kinerja. Artinya dapat ditunjukkan dari temuan tersebut bahwa sebagian besar pemilik Usaha Kecil Menengah (UKM) Kota Surabaya mengikuti pelatihan akuntansi untuk memperbaiki kinerja usaha yang dijalankan dengan begitu usaha yang dikelola dapat berjalan maksimal sesuai yang diinginkan oleh pemilik, sebab sebelumnya pemilik UKM menggunakan informasi akuntansi sebatas pengetahuan yang didapat dari sesama pemilik UKM. Oleh karena itu, dengan adanya pelatihan akuntansi yang diikuti pemilik UKM selain menambah pengetahuan juga dijadikan untuk ajang berkonsultasi oleh pemilik UKM dengan pakar (trainer) bagaimana menggunakan informasi akuntansi dengan baik sehingga usaha yang dijalankan dapat memperoleh hasil maksimal sesuai dengan apa yang diharapkan.

Selain itu, juga didukung oleh temuan pada variabel penggunaan informasi akuntansi didukung oleh indikator pertama yaitu menggunakan informasi akuntansi statutori. Hal tersebut dapat ditunjukkan dengan hasil temuan bahwa sebagian besar pemilik Usaha Kecil Menengah (UKM) Kota Surabaya menggunakan informasi yang harus disiapkan sesuai dengan peraturan yang ada. Artinya laporan keuangan dibuat sesuai dengan panduan dan kaidah-kaidah yang baku sehingga pemilik UKM akan mudah dalam memahami dan mengerti dalam menginterpretasikan data-data pada laporan keuangan untuk pengambilan keputusan yang tepat.

Hasil penelitian ini menunjukkan bahwa pelatihan akuntansi terbukti berpengaruh positif terhadap penggunaan informasi akuntansi mendukung penelitian Grace (2003); Wahyudi (2009); dan Firmansyah (2014) dalam penelitiannya bahwa variabel pelatihan akuntansi menjadi salah satu faktor penting dalam mempengaruhi penggunaan informasi akuntansi Usaha Kecil Menengah (UKM).

Kesimpulan yang diperoleh dalam penelitian ini mendukung penelitian yang dilakukan Astuti (2007) yang menjelaskan bahwa pelatihan akuntansi yang diikuti akan menambah skill pemilik UKM sehingga akan memiliki hubungan positif dalam penggunaan informasi akuntansi Usaha Kecil Menengah (UKM) di Kabupaten Kudus tidak dapat terbukti. Dalam penelitian ini variabel pelatihan akuntansi terbukti menjadi prediktor yang mempengaruhi penggunaan informasi akuntansi Usaha Kecil Menengah (UKM) Kampung Unggulan Kota Surabaya.

\section{Ketidakpastian lingkungan memoderasi pengaruh tingkat pendidikan terhadap penggunaan informasi akuntansi}

Berdasarkan hasil pengujian hipotesis dalam penelitian ini adalah ketidakpastian lingkungan memoderasi (menguatkan) hubungan pengaruh tingkat pendidikan terhadap penggunaan informasi akuntansi Usaha Kecil Menengah (UKM) Kota Surabaya. Walaupun tidak ada pengaruh tingkat pendidikan terhadap penggunaan informasi akuntansi dikarenakan pendidikan 
pemilik UKM masih rendah terhadap informasi akuntansi tetapi dengan adanya variabel moderasi ketidakpastian lingkungan hubungan keduanya diperkuat atau dimoderasi.

Hasil peneletian ini mendukung penelitian sebelumnya yang dilakukan Nalukenge et.al (2012); Zhou (2010) yang menjelaskan bahwa variabel moderasi ketidakpastian lingkungan memoderasi (memperkuat) hubungan pengaruh tingkat pendidikan terhadap penggunaan informasi akuntansi pada Usaha Kecil Menengah (UKM).

Ketidakpastian lingkungan memoderasi pengaruh tingkat pendidikan terhadap penggunaan informasi akuntansi Usaha Kecil Menengah (UKM) Kampung Unggulan Kota Surabaya didukung oleh temuan pada variabel moderasi ketidakpastian lingkungan dalam penelitian ini didukung oleh indikator ketiga yaitu mengenai informasi non ekonomi antara lain: Peraturan pemerintah, artinya setiap ada pergantian pemerintahan tentunya kebijakan yang dilakukan juga akan berubah. Peluang pasar menjadi salah satu faktor penting juga bagaimana produk-produk yang dihasilkan terdapat pangsa pasarnya. Segi persaingan usaha, bagaimana pemilik UKM mampu membuat produk-produk yang kompetitif dan mampu bersaing di pasar sehingga konsumen akan memiliki kepercayaan terhadap produk tersebut. Mengenai prediksi harga, pemilik UKM mampu memprediksi harga dimasa yang akan datang sehingga para pelaku usaha mampu mempertimbangkan dengan baik dan matang dalam memproduksi produk-produknya. Selain itu agar dapat mempersiapkan bahan baku yang digunakan dalam proses produksi. Prediksi harga dimasa mendatang ketika dilakukan dengan tepat maka para pemilik UKM mampu membuat produk yang yang disesuaikan dengan harga dimasa mendatang pula.

Kesimpulan yang diperoleh dari hasil penelitian ini mendukung penelitian Nalukenge (2012) dan Zhou (2010) yang menjelaskan bahwa ketidakpastian lingkungan memoderasi (memperkuat) pengaruh tingkat pendidikan terhadap penggunaan informasi akuntansi pada UKM terbukti. Variabel ketidakpastian lingkungan merupakan salah satu prediktor yang memoderasi pengaruh tingkat pendidikan terhadap penggunaan informasi akuntansi oleh Usaha Kecil Menengah (UKM) Kota Surabaya.

\section{Ketidakpastian lingkungan memoderasi pengaruh pengetahuan akuntansi terhadap penggunaan informasi akuntansi}

Berdasarkan hasil pengujian hipotesis dalam penelitian ini bahwa ketidakpastian lingkungan memoderasi (menguatkan) hubungan pengaruh pengetahuan akuntansi terhadap penggunaan informasi akuntansi Usaha Kecil Menengah (UKM) kampung unggulan Kota Surabaya. Hal ini berarti pengaruh pengetahuan akuntansi terhadap penggunaan informasi akuntansi dimodersai (diperkuat) oleh ketidakpastian lingkungan sebagai variabel moderasi.

Hasil peneletian ini mendukung penelitian sebelumnya yang dilakukan oleh Hadiah Fitriyah (2006) Shonhadji (2006) dan Lasdi \& Mulia (2014) yang mengungkapkan dalam penelitiannya bahwa variabel moderasi ketidakpastian lingkungan memoderasi (memperkuat) pengaruh pengetahuan akuntansi terhadap penggunaan informasi akuntansi pada Usaha Kecil Menengah (UKM). 
Ketidakpastian lingkungan memoderasi pengaruh pengetahuan akuntansi terhadap penggunaan informasi akuntansi Usaha Kecil Menengah (UKM) Kampung Unggulan Kota Surabaya didukung oleh temuan pada variabel moderasi ketidakpastian lingkungan dalam penelitian ini didukung oleh indikator ketiga yaitu mengenai informasi non ekonomi: peraturan pemerintah artinya setiap ada pergantian pemerintahan tentunya peraturan yang menyangkut UKM sedikit banyak akan berubah sehingga hal sedemikian rupa menjadi faktor penting bagaimana penggunaan informasi akuntansi ketika dilakukan dalam suatu usaha. Selanjutnya peluang pasar menjadi salah satu faktor penting juga dalam mendistribusikan produk-produk UKM, hal ini menjadi perhatian pemilik UKM ketika ketidakpastian peluang pasar dimasa yang akan datang tidak sesuai dengan ekspektasi pemilik UKM, kemudian dari segi persaingan usaha, bagaimana pemilik UKM mampu membuat produkproduk yang kompetitif dan mampu bersaing di pasar sehingga produk-produk tersebut dikenal konsumen dan memiliki keunggulan (brand) yang kualitasnya tidak diragukan lagi karena dengan begitu kepuasan konsumen akan terjaga untuk selalu membeli produk-produk hasil produksi Usaha Kecil Menengah (UKM). Kemudian yang terakhir adalah mengenai prediksi harga, pemilik UKM mampu memprediksi harga dimasa yang akan datang sehingga para pelaku usaha mampu mempertimbangkan dengan baik dan matang dalam memproduksi produk-produknya apalagi mempersiapkan dengan baik bahan baku yang digunakan dalam proses produksi. Disaat harga dimasa mendatang baik maka para pemilik UKM mampu membuat produk yang banyak sehingga digunakan sebagai stok untuk kondisi tersebut, sebaliknya ketika harga dimasa yang akan datang tidak mampu diprediksi maka yang terjadi para pemilik UKM lebih mempertimbangkan skala prioritas di dalam proses operasional (produksi) produk.

Kesimpulan yang diperoleh dalam penelitian ini mendukung penelitian Hadiah Fitriyah (2006) yang menyatakan bahwa ketidakpastian lingkungan memoderasi (memperkuat) pengaruh pengetahuan akuntansi terhadap penggunaan informasi akuntansi terbukti. Variabel ketidakpastian lingkungan merupakan salah satu prediktor yang memoderasi (menguatkan) pengaruh pengetahuan akuntansi terhadap penggunaan informasi akuntansi pada Usaha Kecil Menengah (UKM) Kota Surabaya.

\section{Ketidakpastian lingkungan memoderasi pengaruh pelatihan akuntansi terhadap penggunaan informasi akuntansi}

Berdasarkan hasil pengujian hipotesis dalam penelitian ini menunjukkan ketidakpastian lingkungan memoderasi (menguatkan) pengaruh pelatihan akuntansi terhadap penggunaan informasi akuntansi Usaha Kecil Menengah (UKM) kampung unggulan Kota Surabaya. Hal ini berarti pengaruh positif pelatihan akuntansi terhadap penggunaan informasi akuntansi dimodersai (diperkuat) oleh ketidakpastian lingkungan sebagai variabel moderasi.

Hasil peneletian ini mendukung penelitian sebelumnya yang dilakukan oleh Mc.Mahon (2001), serta penelitian Shield dan Shelleman (2011) menjelaskan dalam penelitiannya bahwa variabel moderasi ketidakpastian lingkungan memoderasi (memperkuat) pengaruh pelatihan akuntansi terhadap penggunaan informasi akuntansi pada Usaha Kecil Menengah (UKM). 
Ketidakpastian lingkungan memoderasi pengaruh positif pelatihan akuntansi terhadap penggunaan informasi akuntansi Usaha Kecil Menengah (UKM) Kampung Unggulan Kota Surabaya didukung oleh temuan pada variabel moderasi ketidakpastian lingkungan dalam penelitian ini didukung oleh indikator ketiga mengenai informasi non ekonomi: peraturan pemerintah artinya setiap ada pergantian pemerintahan tentunya peraturan yang menyangkut UKM sedikit banyak akan berubah sehingga hal sedemikian rupa menjadi faktor penting bagaimana penggunaan informasi akuntansi ketika dilakukan dalam suatu usaha. Selanjutnya peluang pasar menjadi salah satu faktor penting juga dalam mendistribusikan produk-produk UKM, hal ini menjadi perhatian pemilik UKM ketika ketidakpastian peluang pasar dimasa yang akan datang tidak sesuai dengan ekspektasi pemilik UKM, kemudian dilihat dari segi persaingan usaha, bagaimana pemilik UKM mampu membuat produk yang kompetitif dan mampu bersaing di pasar sehingga produk yang dihasilkan tersebut dikenal konsumen dan memiliki keunggulan (brand quality) yang kualitasnya tidak diragukan lagi karena dengan begitu kepuasan konsumen akan terjaga untuk selalu membeli produk-produk hasil produksi Usaha Kecil Menengah (UKM).

Kemudian untuk yang terakhir adalah mengenai prediksi harga, pemilik UKM mampu memprediksi harga dimasa mendatang sehingga pemilik UKM dapat mempertimbangkan dengan baik dan matang dalam memproduksi produk-produknya apalagi mempersiapkan dengan baik bahan baku yang digunakan dalam proses produksi. Disaat harga dimasa mendatang baik maka para pemilik UKM mampu membuat produk yang banyak sehingga digunakan sebagai stok untuk kondisi tersebut, sebaliknya ketika harga dimasa yang akan datang tidak mampu diprediksi maka yang terjadi para pemilik UKM lebih mempertimbangkan skala prioritas di dalam proses operasional (produksi) produk.

Kesimpulan yang diperoleh dalam penelitian ini mendukung penelitian Mc.Mahon (2001) dan penelitian yang dilakukan Shield dan Shelleman (2011) yang menjelaskan bahwa variabel ketidakpastian lingkungan memoderasi (memperkuat) pengaruh pelatihan akuntansi terhadap penggunaan informasi akuntansi pada UKM terbukti. Variabel ketidakpastian lingkungan merupakan salah satu prediktor yang memoderasi (memperkuat) pengaruh pelatihan akuntansi terhadap penggunaan informasi akuntansi oleh Usaha Kecil Menengah (UKM) Kota Surabaya.

\section{SIMPULAN}

Berdasarkan hasil penelitian yang telah diuraikan, maka dapat disimpulkan bahwa pada penelitian ini variabel tingkat pendidikan tidak berpengaruh terhadap penggunaan informasi akuntansi pada Usaha Kecil Menengah (UKM) Kota Surabaya. Pengetahuan akuntansi berpengaruh signifikan terhadap penggunaan informasi akuntansi pada Usaha Kecil Menengah (UKM) Kota Surabaya. Hal ini berarti semakin baik pengetahuan akuntansi yang dimiliki oleh pemilik UKM maka akan semakin baik pula penggunaan informasi akuntansi yang dilakukan. Kemudian Pelatihan akuntansi berpengaruh signifikan terhadap penggunaan informasi akuntansi 
pada Usaha Kecil Menengah (UKM) Kota Surabaya. Hal ini berarti semakin banyak pelatihan akuntansi yang diikuti oleh pemilik UKM maka akan semakin baik penggunaan informasi akuntansi yang dilakukan. Ketidakpastian lingkungan sebagai variabel moderasi memoderasi (menguatkan) pengaruh tingkat pendidikan, pengetahuan akuntansi dan pelatihan akuntansi terhadap penggunaan informasi akuntansi pada Usaha Kecil Menengah (UKM) Kota Surabaya. Hal ini berarti dengan adanya variabel moderasi ketidakpastian lingkungan menguatkan (memoderasi) pengaruh tersebut khususnya yang berkaitan dengan ketidakpastian lingkungan mengenai informasi non ekonomi seperti: Peraturan pemerintah, peluang pasar, persaingan usaha, dan prediksi harga.

\section{DAFTAR RUJUKAN}

Astuti, Era. 2007. Pengaruh Karakteristik Internal Perusahaan Terhadap Penyiapan dan Penggunaan Informasi Akuntansi Perusahaan Kecil dan Menengah di Kabupaten Kudus. Universitas Diponegoro: Semarang.

Astuti, Sih Darmi., Widiatmoko, J. 2003. Profil Usaha Kecil Menengah UKM Jawa Tengah. Fokus Ekonomi. Vol.2 No.3, 215-228.

Badan Pusat Statistik 2014. Statistik Daerah Kota Surabaya 2014. Surabaya: BPS Kota Surabaya.

Badan Pusat Statistik. 2014. Surabaya Dalam Angka, Surabaya in Figures 2014. Surabaya: BPS Kota Surabaya.

Badan Pusat Statistik. 2014. Produk Domestik Regional Bruto Kota Surabaya 2009-2013. Surabaya: BPS Kota Surabaya.

Barbara, Orser J., Sandy Hogart-Scott, and Allan L. Riding. 2000. Performance, Firm Size, and Management Problem Solving. Journal of Small Business Management. pp.112-120.

Belkaoui, A.R. 2000. Teori Akuntansi. Jakarta: Salemba Empat.

Bonner, S.E., \& Walker, P.L. 1994. The Effect of Instruction and Experience on The Acquitition of Auditing Knowledge, The Accounting Review. Vol. 69 No. 1 pp. 157-178.

Chiliya, Norman., Lombart, M.R. 2012. Impact of Level Education and Experience on Profitability of Small Grocery Shop in South Africa. International Journal Business, Management, Economic Research. Vol.3 No.1. pp. 462-470.

Darlis, Edfan. 2002. Analisis Pengaruh Komitmen Organisasional dan Ketidakpastian Lingkungan terhadap Hubungan Antara Partisipasi Anggaran dengan Senjangan Anggaran. Jurnal Riset Akuntan Indonesia. Ikatan Akuntan Pendidik Komparteman Akuntan Pendidik. Vol. VIII. No.2. September 2002. Pp. 297-313. 
Departemen Koperasi dan UKM Republik Indonesia. 2012. Investasi, Tenaga Kerja, PDB, Unit UMKM di Indonesia. Jakarta: Depkop UKM.

Duncan, RB. 1972. Characteristic of Organization Environment and Perceived Environment Uncertainty, Administration Science Quartely 17: 313-327, in Gregson, Teryet.al. 1994. Role Ambiguity, Role Conflict, and Perceived Environment Uncertainty: Are the Scale Measurement Separate Construct For Accountants?, Behavioral Research in Accounting 6: 145-159.

Firmansyah, Rakhmad Ady. 2014 Analisis Faktor-Faktor yang Mempangaruhi Penggunaan Sistem Informasi Akuntansi Pada Usaha, Kecil dan Menengah Kota Malang. Jurnal Ilmiah Mahasiswa FEB UB. Vol.2 No.2.

Fisher, Cathy. 1996. The Impact of Perceived Environmental Uncertainty and Individual Difference on Management Information Requirements: A Research Note, Accounting, Organization and Society. Vol. 21. No.4. pp. 361-369.

Fitriyah, Hadiah. 2006. Analisis Faktor-Faktor yang Mempengaruhi Penggunaan Informasi Akuntansi Pada Usaha Menengah Kabupaten Sidoarjo. Surabaya: Universitas Airlangga.

Ghozali, Imam. 2006. Analisis Multivariate dengan Program SPSS. Semarang: Badan Penerbit UNDIP.

Gordon, L. \& Miller, D. 1976. A Contigency Framework for the Design of Accounting Information System: Accounting, Organizations and Society. 11. 59-69.

Grace, Tiana Solovida. 2003. Analisis Faktor-Faktor yang Mempengaruhi Penyiapan dan Penggunaan Informasi Akuntansi pada Perusahaan Kecil dan Menengah di Jawa Tengah. Semarang. Universitas Diponegoro.

Grande, E.U., Estebanez, R.P., Colomina, C.M. 2011. The Impact of Accounting Information System AIS on Performance Measures: Empirical Evidence in Spanish SMEs. The International Journal of Digital Accounting Research.Vol. 11. pp. 25-43.

Gudono. dan Susanto. 2007. Pengaruh Intensitas Kompetisi Pasar Terhadap Hubungan Antara Penggunaan Informasi Sistem Akuntansi Managemen dan Kinerja Unit Bisnis dan Kepuasan Kerja. Simposium Nasional Akuntansi X. Makassar.

Haswell, S., \& Holmes, S. 1989. Estimating The Small Business Failure Rate: A Reappraisal. Journal of Small Business Management. Vol.27. No.3. pp. 68.

Holmes, S., and Nicholls, D., 1988. An Analysis of The Use of Accounting Information by Australian Small Business. Journal of Small Business Management. 26 20. pp 57-68. 
Holmes, S., and Nicholls, D., 1989. Modelling The Accounting Information Requirements of Small Business. Accounting and Business Research. Vol. 19. No. 74. Pp. 60-76.

Ihsan, Fuad. 2011. Dasar-dasar Kependidikan. Jakarta: Rineka Cipta.

Ismail, N.A., and King, M., 2005. Firm Performance and AIS Alignment in Malaysian SMEs. International Journal of Accounting Information System. Vol. 6 No.4. pp. 241-259.

Jawa Pos, 2014. Mayoritas Usaha Kecil belum Siap Pasar Bebas. Surabaya: Jawa Pos Edisi 7 Desember 2014.

Lasdi, Lodovicus \& Winda Mulia, T. 2014. Company's Internal Characteristics, Environmental Uncertainty, The Use of Accounting Information, and The Performance of SMEs. Journal of Economics, Business, and Accountancy Ventura. Vol.17 No.1. pp. 105-116.

Mc Mahon, R.G.P. 2001. Business Growth and Performance and The Financial Reporting Practice of Australia Manufacturing SMEs, Journal of Small Business Management. Vol. 39. No.2. pp. 152-164.

Miliken, F.J. 1987. Three Types of Uncertainty About The Environment: State, Effect, and Response Uncertainty. Academy of Management Review. (121): 133-143.

Mitchell, F., Reid, G., and Smith, J. 2000. Information System Development in The Small Firm: The Use of Management Accounting. CIMA Publishing.

Nalukenge, Irene., Nkundabayanga, Stephen K., Tauringana, Venancio. 2012. Litercy, External User-Pressure and Quality of Accounting Information of Ugandan SMEs, in Venancio Tauringana, Musa Mangena ed.. Book series: Accounting in Africa Research in Accounting in Emerging Economies. Vol. 12 Part.A. Emerald Group Publishing Limited. Pp. 5173.

Shields, J.F., Shelleman, J.M. 2011. Management Accounting Reports in Small Businesses: Frequency of Use and Influence of Owner Locus of Control and Goals. Small Business Institute Journal. Vol.7. pp. 29-51.

Shonhadji, N. 2009. Pengaruh Pengetahuan Akuntansi, Wirausaha Locus of Control dan Ketidakpastian Lingkungan Terhadap Penggunaan Informasi Akuntansi dalam Pengambilan Keputusan Investasi. Jurnal Ekonomi Bisnis \& Akuntansi. 12.

Son, D.D., Marriot, N. and Marriot, P. 2006. Users' Perception and Uses of Financial Reports of Small and Medium Companies in Transitional Economies: Qualitative Evidence From Vietnam, Qualitative Research in Accounting \& Management. Vol. 3 No.30 pp. 218-235. 
Spilker, Brian C., 1995. The Effect of Time Pressure and Knowledge on Key Word Selection Behavior in Tax Research. The Accounting Review. Vol.70 No. 1 pp. 49-70.

Suhairi, S. Y., Haron, H. 2004. Pengaruh Pengetahuan Akuntansi dan Kepribadian Wirausaha Terhadap Penggunaan Informasi Akuntansi dalam Pengambilan Keputusan Investasi. Simposium Nasional Akuntansi VII. Denpasar.

Undang-Undang Republik Indonesia Nomor 20 Tahun 2003. Tentang Sistem Pendidikan Nasional. Jakarta: Depdiknas.

Wahyudi, Muhammad. 2009. Analisis Faktor-Faktor yang Mempengaruhi Penggunaan Informasi Akuntansi Pada Usaha Kecil dan Menengah UKM di Yogyakarta. Semarang: Universitas Diponegoro.

Zhou, Lijuan. 2010. The Research on Issue and Countermeasures of Accounting Information of SMEs. International Journal of Business and Management. Vol.5 No. 3. Pp. 223-225. 